\title{
6
}

\section{A Tango of Two Superpowers: China-US-Timor-Leste Trilateral Cooperation on Food Security}

\section{Introduction}

Chapters 4 and 5 have examined China's engagement in development cooperation with the UNDP and with Australia in the Asia-Pacific region. By tracing the process of the China-UNDP-Cambodia trilateral cassava project and the China-Australia-PNG trilateral malaria project, the analysis concluded that China endorsed these projects for two main reasons. First, China is keen to use development cooperation to project its image as a responsible cooperative partner in the eyes of the UNDP and Australia, which is significant to China's multilateral diplomacy and to diplomacy in the Pacific region. Second, thanks to the decades-long interaction with the UNDP and Australia regarding aid, China has realised that cooperating with these two partners through a trilateral aid partnership would be beneficial for learning how to improve its aid delivery.

This chapter ${ }^{1}$ will continue to test China's trilateral aid cooperation in Asia. It will discuss China's trilateral aid cooperation with the US, which is the earliest provider of development assistance. The modern concept of foreign aid started when the US initiated the Marshall Plan to provide aid to Western Europe after World War II in 1947 (Marshall Foundation,

1 This chapter is derived in part from an article published in Asian Journal of Political Science on 9 April 2018, doi.org/10.1080/02185377.2018.1462218. 
2015). The US is also the largest traditional donor; in 2017, its net aid volume reached $\$ 35.26$ billion, accounting for 24 per cent of the total aid from the OECD DAC (OECD, 2018).

China, the leading emerging donor, has been providing a growing amount of foreign assistance overseas. With its unique features in foreign aid, China has significantly influenced the traditional aid regime. The US has been the most vocal critic of Chinese aid. Then US Secretary of State Hillary Clinton argued that Chinese aid raised serious concerns and that the US wanted to promote common aid standards and approaches (Clinton, 2011). She also warned developing countries against cooperating with emerging donors like China, who are more interested in exploiting natural resources than in promoting real development (Bland \& Dyer, 2011; Ghosh, 2012).

More than that, the US has taken actions to offset China's growing influence. This is notable, even in the Pacific Island countries (Firth, 2013, pp. 1-3). In her testimony on foreign aid before the US Senate foreign relations committee in March 2011, Hillary Clinton explicitly stated that 'we are in a competition for influence with China' (Pennington, 2011). In 2012, Hillary Clinton became the first US secretary of state to attend the Pacific Islands forum post-forum dialogue in the Cook Islands. While noting that 'the Pacific is big enough for all of us', she declared that 'the 21 st century will be America's Pacific century, with an emphasis on the Pacific' and that the US will stay 'for a long haul' (Clinton, 2012, paras 3-4, 14). She pledged an aid package of $\$ 32$ million on top of America's annual aid of $\$ 330$ million to the region (Larsen, 2012), which starkly contrasts the US's aid cut in the past two decades. In addition, USAID opened its office in PNG in 2011 and provided $\$ 100$ million in military aid to the region (Larsen, 2012). Since 2018, the Trump administration has vowed to implement its Indo-Pacific strategy to compete with China-funded infrastructure projects in the region (Pompeo, 2018).

However, in this context of rivalry, China and the US have begun exploring development cooperation in recent years, bringing hope to the international community that, at least in the development arena, these two superpowers can join hands together to deliver aid to Third World countries. Presently, China and the US have conducted the following trilateral aid projects: the Fendell Campus project of the University of Liberia (2008-2010) (China Embassy in Liberia, 2008; VOA, 2009); peacekeeping in Liberia (2008) (Christensen \& Swan, 2008); the project 
on food security in Timor-Leste (2013-2014) (Zhang, 2015); and the joint training project of Afghan diplomats (since 2012) (Zhang \& Ye, 2015).

This chapter is organised as follows. First, it will examine the ChinaUS engagement in development cooperation and conclude that China's perceptions of development cooperation with the US have changed, especially from China's image-building perspective. Second, it will analyse the evolving trends in aid to Timor-Leste, including China's footprint. Section three will provide a detailed case study of the China-US-TimorLeste trilateral project on food security and it will reveal the motivations of the three countries, especially China. The last section will discuss the prospect of China-US trilateral aid cooperation amid growing uncertainties in the bilateral relations.

\section{China-US Engagement in Development Cooperation}

Similar to China's engagement with other traditional donors in trilateral aid cooperation, the US has played a more proactive role in this process. However, the China-US engagement in development cooperation presents distinctive features. First, the US began its aid program in China in 1999, much later than many other traditional donors. This has greatly limited China's engagement in and learning from US aid practices. The second feature is that the diplomatic flavour is more visible during China-US interactions, as they have used aid cooperation as a tool to serve their bilateral relations. However, this does not invalidate my argument that engagement leads to mutual learning and ideational change because the China-US engagement is limited compared to other traditional donors.

\section{Learning from US Aid}

The US Congress began authorising funding in 1999 to promote democracy in China $^{2}$ (US General Accounting Office, 2004, p. 1). In 2000, the US Act that was granting permanent normal trade relations

2 The Foreign Assistance Act 1961 of the US stipulated that communist nations, including China and its Tibetan region, are ineligible to receive US aid. This clause was repealed in December 1985. However, US aid to China did not start until the late 1990s. One reason relates to the US's sanction on China after the 1989 Tiananmen Square. 
treatment to China approved aid programs to foster the rule of law and civil society in China (Lum, 2013, p. 5). According to a US expert on China, the US aid programs started late in China due to the substantial differences between the two countries in areas such as trade, security and human rights. Therefore, the US government felt it was inappropriate to provide aid to China. Additionally, the Chinese government did not accept US aid until some agreements were reached (Email interview, Canberra, 8 December 2015).

US aid to China is mainly administered by the Department of State and USAID. The funding is mainly channelled through US-based non-governmental organisations (NGOs) and universities rather than the Chinese government (Lawrence, 2013, p. 14; Lum, 2013, p. 1). The US was the fifth-largest donor in China, totalling $\$ 63.3$ million in 2012, and the largest provider of support for NGOs and civil society programming in China (Lum, 2013, p. 2). Interestingly, the US prefers to call its assistance to China 'international programs' rather than 'aid' (Fish, 2013).

Unlike many other traditional donors, the US focuses its aid programs in China on the following three areas rather than on economic development: promoting employment creation, management of natural resource-based livelihood and the preservation of cultural heritage in Tibet; addressing cross-border challenges, including HIV/AIDS, infectious diseases and wildlife trafficking; and promoting the rule of law and reducing greenhouse gas emissions (USAID, 2015d). For example, the US allocated approximately $\$ 62$ million between 2002 and 2014 for its programs in Tibet and Tibetan communities in China (Lum, 2013, p. 8).

US aid to China became controversial in 2011, as China overtook Japan as the second-largest economy in 2010; US aid to China peaked to its highest level in 15 years (Fish, 2013). It became an issue in US domestic politics because some politicians used this to attack the government. In November 2011, some members of the US House of Representatives criticised the USAID programs in China, arguing that the US 'borrow[s] money from China to give back to China to help it fix its own domestic problems' and that this demonstrates 'the dysfunction in America's foreign aid spending priorities' (US Government, 2011). This is a parallel with the Chinese government's dilemma in selling its growing aid program to the domestic audience when a large population of poverty remains at home. 


\section{Learning Influence}

China has expressed its desire to learn from US aid delivery. In 2007, Chinese Ambassador to Ethiopia Lin Lin noted that China would consider technical cooperation between China's telecommunication company ZTE and their US counterparts in Ethiopia, such as subcontracting some US firms because ZTE lacked the technical expertise in areas including fibre optics (Wikileaks, 2007). In 2009, China and the US signed an MOU in regard to agricultural cooperation, which was renewed in September 2015. The two countries agreed to cooperate in areas such as food security, capacity building and personnel exchanges (Ministry of Agriculture, 2015).

John Kamm, the founder of Dui Hua, a US-based non-profit humanitarian organisation, argued that China's engagement with the international community including the US has contributed significantly to criminal justice reform in China. He expected that China would continue the international exchanges while eschewing sensitive areas such as political rights and freedom (Lum, 2013, p. 4).

However, the short history of US aid to China and its focus on sensitive areas in China have led to limited engagement and learning compared to China's engagement with other donors (Zhang, 2018). US aid to China is consequently out of the spotlight in China. For example, the Chinese government allows the US aid program to continue in Tibet because it does not focus on sensitive areas such as democracy and the rule of law; however, it prohibits the US Peace Corps from working in Tibet (Fish, 2013), though they are allowed to operate in Sichuan, Gansu, Guizhou and Chongqing. Mention of US aid to China from Chinese officials and in the media is rare. Related research is also limited, except for a handful of articles focusing on the strategic motivations of US aid (Liu, 2010; Zhou, 2002, 2013).

\section{Global Image-Building}

As I have argued in Chapter 3, the learning imperative through long-term interactions and global image-building are the two main driving forces behind China's trilateral aid cooperation. While the learning imperative is less obvious in China-US engagement, global image-building has played a notable role in this process. 
To elaborate, global image-building has played three roles in China's trilateral cooperation with the US and recipient countries. First, by engaging in trilateral aid cooperation, China hopes to reduce criticism from the US, which is the largest traditional donor and the most vocal critic of Chinese foreign aid. Second, working with the US in areas of critical importance to the recipient countries such as food security and public health is conducive to China's image as a responsible great power. For example, to improve its aid effectiveness and rebut the accusations of a 'China threat' and 'neo-colonialism', China has increased the number of livelihood-related aid projects, including establishing malaria control centres and agricultural demonstration farms in Africa.

Most importantly, global image-building carries a heavy responsibility in China's diplomacy to project a positive image as a responsible stakeholder to facilitate broad China-US relations. At the 10th conference of ambassadors held in Beijing in 2004, China's President Hu Jintao stressed that relations with the big powers are a priority (da guo shi guanjian) in China's diplomacy (Chen, 2009). As the US is the only superpower and the dominant force in international relations, Chinese leaders and working-level officials attribute extreme importance to China-US relations. China's President Xi Jinping emphasised during his visit to the US in September 2015 that 'win-win cooperation is the only right choice for the China-US relations' and that the two countries should cooperate in providing more public goods to the international community (MFA, 2015b; 2015c, para. 14).

Using development cooperation as an example, the Chinese government hopes to convince the US that China is a trustworthy partner and that it is ready to work with the US to improve their bilateral relationship. This feature will be prominent in the following discussion.

\section{Development Cooperation: Serving Broad China-US Relations}

To make China a responsible stakeholder was the goal of the Clinton administration in the 1990s, as well as of the following Bush administration (Donnelly \& Monaghan, 2007, p. 2). According to Thomas Donnelly and Colin Monaghan, the Clinton administration worked to establish a strategic partnership with China under an engagement policy. During the election campaign and in the early days of his presidency, George W. Bush believed China to be a threat rather than a partner for cooperation. 
The terrorist attacks on 11 September 2001 were a turning point. The US worked to seek China's support in the counterterrorism campaign: 'China pledged to play a constructive role in international counterterrorism efforts and the Bush administration pledged to pretend that the Chinese were doing so' (Donnelly \& Monaghan, 2007, p. 2; Zhang, 2018).

It remained a primary task of the successive US governments to engage with China and make the country a responsible player in global affairs, until President Trump changed the tone. During her visit to China in March 2005, then US Secretary of State Condoleezza Rice said that the US 'look[ed] forward to a confident and a good partner in China' to address common challenges and that she was quite sure that the two countries would 'be able to manage the many issues before us and we will be able to do so in a spirit of cooperation and respect for one another' (US Department of State, 2005a). The term 'responsible stakeholder' was coined by US Deputy Secretary of State Robert Zoellick in his remarks to the National Committee on US-China relations in September 2005.

For the United States and the world, the essential question ishow will China use its influence? To answer that question, it is time to take our policy beyond opening doors to China’s membership into the international system: We need to urge China to become a responsible stakeholder in that system ... In its foreign policy, China has many opportunities to be a responsible stakeholder ... The US response should be to help foster constructive action by transforming our thirty-year policy of integration: We now need to encourage China to become a responsible stakeholder in the international system. As a responsible stakeholder, China would be more than just a member. It would work with us to sustain the international system that has enabled its success. (US Department of State, 2005b, paras 9, 32, 55)

The Chinese side has approached this term with caution. Xinhua, China's official news agency, cited an article on its website interpreting this term as US willingness to cooperate with China on the one hand and a sense of suspicion towards China on the other. It argued that this reveals the sentiment of engagement and containment from the US in its relations with China (Xinhua, 2006). Then Chinese Minister of Foreign Affairs Li Zhaoxing stated that 'China and the US are not only stakeholders but also should be partners of constructive cooperation' (Xinhua, 2006, para. 6). 
The US began dedicating more diplomatic efforts to engage with China. US officials on African affairs initiated a policy of engagement with China in Africa, and the US State Department's African bureau began to focus on China's engagement in Africa since July 2005 (Shinn, 2009, p. 5). Michael Ranneberger, deputy assistant secretary of state for African affairs, encouraged the US side to identify areas of common interests for US-China cooperation (e.g. peacekeeping). He argued that 'the future of US-China relations in Africa has yet to be charted, but a focused, direct dialogue is an essential starting point' (US House of Representatives, 2005).

In December 2005, Steve Tvardek, director of the Office of Trade Finance from the US Department of Treasury, and Piper Starr from the US ExportImport Bank met with Chinese officials from MOFCOM, the China Exim Bank and the China Export and Credit Insurance Cooperation in Beijing and exchanged views on development issues (Wikileaks, 2008e). The engagement policy was further emphasised in 2008. In June of that year, Thomas J. Christensen, deputy assistant secretary for East Asian and Pacific affairs, and James Swan, deputy assistant secretary for African affairs, said before the Senate Foreign Relations Committee that:

We see China's growing activity on the continent [Africa] as a potentially positive force for economic development there ... As President Bush has said, we do not see a 'zero-sum' competition with China for influence in Africa ... Our goal is to engage Chinese officials to try to define and expand a common agenda for Africa that ultimately will serve both our national interests and maximize the benefit Africa derives from US and Chinese economic investment in the continent. We are actively looking for areas of complementarity and cooperation with the Chinese. (Christensen \& Swan, 2008)

In 2008, the US government created a new position of development counsellor at its embassy in Beijing 'to better understand China's foreign assistance structure and establish a working relationship with key Chinese entities responsible for implementing its foreign assistance programs' (USAID China, 2013, para. 6). The Obama administration continued the engagement policy and announced that the US welcomed China's peaceful rise (Lawrence, 2013, p. 5). To President Obama, it was more useful for the US to increase its engagement with China than to sit back and complain about China's growing influence in Africa (Shinn, 2012b). He made it clear that the US needed to 'draw China into the international system and work with it on shared political, economic, environmental 
and security objectives' (Jia, 2010, p. 254). Development cooperation is part of this process. It worth noting that the competitive flavour between the two superpowers has become more evident since 2013.

\section{Cooperation in Africa}

Africa has been a top recipient of both US and Chinese aid. The Bush administration significantly increased its aid to Africa and the trend continued in the Obama era. The US annual aid budget to Africa has been approximately $\$ 8$ billion in recent years (Shinn, 2015). Africa has long been strategically regarded as a cooperative partner by the Chinese government, since the PRC was founded in 1949. Africa receives approximately half of China's overseas assistance (State Council, 2011d, 2014).

China's rapidly growing footprint in Africa in recent years, especially after the 2006 summit forum on China-Africa cooperation, has alarmed the US government as a challenge to US influence in Africa. As a response, the US began increasing its engagement with China in development assistance in the late Bush administration (Lu Boynton \& Savoy, 2012, p. 8) —which was a move to boost US understanding of China's presence in Africa and to influence Chinese aid practices. It is unsurprising that engagement in development cooperation began in Africa.

The first China-US dialogue on African affairs was convened in 2005. Jendayi Frazer, assistant secretary of state for African affairs, suggested that the two countries cooperate with African countries in the sectors of infrastructure, agriculture and health to avoid overlapping aid projects and to improve the efficient use of resources (Shinn, 2012b). Early in the Obama administration, US embassies in Africa were instructed to report back more analysis on China's activities in Africa (Shinn, 2012b).

David H. Shinn, adjunct professor from George Washington University and former US ambassador to Ethiopia and Burkina Faso, echoed the potential for trilateral development cooperation. Based on his 37-yearlong career in the US Foreign Service and his extensive working experience in Africa, he argued that the US and China have surprisingly similar interests in Africa, including ensuring access to natural resources, obtaining political support, expanding export markets and minimising the effects of terrorism, international crime and narcotics; he stated that there are numerous areas for cooperation (Shinn, 2015). He suggested 
that the two countries cooperate in areas of malaria control, treatment of neglected tropical diseases (including hookworms and schistosomiasis) and pandemic preparedness, arguing that 'Africa is an ideal location for the United States and China to reduce mutual suspicion and benefit African countries at the same time' (Shinn, 2012a, para. 12). The US embassies in Africa have continued to explore trilateral cooperation with Chinese embassies. In December 2015, Joyce Winchel Namde, chargé d'affaires of the US embassy in Chad, met with her counterpart, Nie Bo, from the Chinese embassy and expressed willingness to undertake trilateral aid cooperation with China in Chad (MFA, 2015f).

\section{Track Two Engagements}

For cooperation in unfamiliar or sensitive areas, the Chinese government prefers to allow China's semi-official think tanks to test the water. In 2005, the Brenthurst Foundation initiated the Africa-China-US trilateral dialogue mechanism on cooperation in Africa, and China responded affirmatively to the invitation (Brenthurst Foundation, Chinese Academy of Social Sciences, Council on Foreign Relations \& Leon H. Sullivan Foundation, 2007). In partnership with the Brenthurst Foundation, the US Council on Foreign Relations and the Leon H. Sullivan Foundation, the China Academy of Social Sciences (CASS) co-hosted three meetings in 2006 and 2007 to continue the discussions.

Delegates from China, the US and African countries exchanged views on numerous areas, including globalisation, democratisation and governance, peace and security and corporate social responsibility. They particularly discussed areas for potential trilateral cooperation (Brenthurst Foundation et al., 2007, pp. 3-4). For example, Witney Schneidman, former deputy assistant secretary of state for African affairs, argued that China and the US could jointly assist African countries in conflict prevention, integration into the global economy, health (malaria and HIV), energy, governance and capacity building (Brenthurst Foundation et al., 2007, p. 15). Chinese delegates suggested that the three sides cooperate in areas such as malaria control and health personnel training (Brenthurst Foundation et al., 2007). A similar trilateral dialogue was held in Washington in 2013. CASS scholars He Wenping and Yang Guan argued that there is potential for China-US-Africa cooperation in education, health, infrastructure and security (Brookings Institute, China CASS \& University of Ghana, 2013). 


\section{Evolving Position on Development Cooperation with the US}

The attitude of China, especially that of MOFCOM, towards trilateral aid cooperation with the US has gradually changed for the positive. As will be elaborated in the following discussion, this is the result of China's high-level support and its diplomatic efforts to engage with the US in building a stable China-US relationship for the sake of China's development and security.

A typical example is the China-US global issues forum-a platform for discussing global issues, such as development cooperation. On 13 April 2005, the first forum meeting was co-chaired by Assistant Foreign Minister Shen Guofang and Under Secretary of State for Global Affairs Paula Dobriansky in Washington DC. During the segment on humanitarian assistance, poverty alleviation and development financing, views were exchanged regarding development financing, the MDGs and the ways of supporting and improving the international response to humanitarian assistance (Boucher, 2005). Officials from China's MFA, Ministry of Public Security, Ministry of Health and State Environmental Protection Administration attended the meeting. In stark contrast, MOFCOM as China's leading aid agency did not attend. This could be perceived as a signal for MOFCOM's lack of interest and confidence in exploring development cooperation with the US in the first place (Zhang, 2018).

MOFCOM attended the second forum meeting in Beijing in August 2006. Although it was represented by officials from DITEA — the agency that oversees foreign aid to China instead of the DFA, which manages Chinese aid overseas - this was progress compared to MOFCOM's absence from the first forum meeting. It demonstrated the importance that MOFCOM attributed to the broad China-US relationship.

China's Assistant Minister of Foreign Affairs Cui Tiankai emphasised at the meeting that it would be in the strategic interests of China and the US to cooperate and address common global challenges. China was open to development cooperation with the US in poverty alleviation, development assistance, development financing, improvement of aid effectiveness and efficiency (MFA, 2006). Norman Nicholson, director for donor coordination at USAID, presented US views on foreign aid and 
development cooperation. Chinese officials expressed appreciation for this introduction and said that this kind of dialogue on foreign aid issues would yield positive results in the long run (Wikileaks, 2006).

China's MFA has been more active than MOFCOM in piloting trilateral aid cooperation with the US, as analysed in Chapter 3. Nicholson's observations in China provided further evidence. He met with MFA officials at the sidelines of the forum meeting. Deputy Director-General Wang Xiaolong from the MFA Department of International Organizations and Conferences said that China wanted to learn from other donors to improve its own aid delivery (Wikileaks, 2006). Zhang Yiming, division director for Pakistan, Afghanistan and Bangladesh from the MFA Department of Asia, said that China was interested in conducting aid cooperation with the US in Afghanistan, especially in humanitarian assistance in droughtstricken areas (Wikileaks, 2006). However, officials from the MOFCOM DFA did not meet with Nicholson (Wikileaks, 2006).

MFA officials continued highlighting the cooperation between China and the US. During his meeting with US Deputy Secretary of State Negroponte in March 2007, China's Deputy Foreign Minister Dai Bingguo said that the two countries should promote dialogue and cooperation (MFA, 2007). Negroponte discussed a possible dialogue on development assistance with Dai (Wikileaks, 2008b).

The US's engagement with China in development cooperation in Africa began to yield results. In October 2007, Chinese Ambassador to Ethiopia Lin signalled China's willingness to explore trilateral aid cooperation with the US in Ethiopia. He welcomed the suggestion from US Ambassador Yamamoto that the two embassies exchange reciprocal visits to their demonstration farms in Ethiopia and that they explore trilateral cooperation in agriculture and food security in the country (Wikileaks, 2007). China MFA officials and scholars stated that China preferred to start trilateral cooperation with discreet projects and then expand them when mutual trust and benefits had been established between China, traditional donors and recipient countries (Wikileaks, 2007). To these agents, the exchange of views on the demonstration farms of China and the US in Ethiopia could be a suitable first step (Wikileaks, 2007).

In May 2007, facilitated by China’s MoF, Director-General Wang Shichun from the MOFCOM DFA met with visiting US Deputy Assistant Secretary of Treasury for International Development Finance and Debt 
Kenneth Peel. This was the first meeting of its kind, as aid officials from the MOFCOM DFA previously refused to meet and discuss aid cooperation with US embassy staff (Wikileaks, 2008e). Peel encouraged China to agree to a long-term bilateral dialogue on development assistance under the US-China strategic and economic dialogue. Director-General Wang agreed to exchange ideas on this issue (Wikileaks, 2008e).

In August 2007, Charles Aanenson, counsellor at the US Embassy in Japan, met with MOFCOM's Deputy Director-General Liu Junfeng from the DFA. Liu said that China and the US should explore potential aid cooperation in Africa and that they should start identifying specific aid projects for cooperation in Third World countries (Wikileaks, 2008e). This demonstrates that the attitude of the MOFCOM DFA regarding development cooperation with the US was softening.

From 2008, the US has amplified its engagement with the Chinese government in development cooperation. In addition to setting up the USAID counsellor position in Beijing in 2008, the US began raising the proposal for development cooperation directly with China's top leaders. On 16 January 2008, US Deputy Secretary of State Negroponte visited China for the bilateral senior dialogue and met with Chinese Premier Wen Jiabao. Negroponte proposed that the two countries should establish a bilateral dialogue on development assistance, and Premier Wen supported the idea (Wikileaks, 2008b). Wen suggested that China and the US enhance mutual understanding and trust through regular mechanisms, such as their bilateral strategic dialogue, and that they should deepen their cooperation for mutual benefits (Xinhua, 2008).

On the margins of this high-level dialogue, USAID Policy Planning Director David Gordon met with MOFCOM Deputy Director-General Wang Hongbo from the Department of American and Oceania Affairs in Beijing on 17 January 2008. Gordon said that the US was not opposed to China's foreign aid and economic activities overseas and that the US shared with China many similar goals in development overseas (Wikileaks, 2008b). He reiterated the US's desire to have a dialogue on foreign aid to improve the understanding of each other's foreign aid goals and strategies. Wang apologised for the unavailability of aid officials from the DFA for the meeting due to their previously determined schedule, but she promised to share the proposal with them and other ministries, stating that the many high-level dialogues between China and the US underscored the importance of this bilateral relationship (Wikileaks, 2008b). 


\section{Vice Ministerial-Level Meeting on Development Cooperation}

Though MOFCOM began to open the door for dialogue with USAID, it was not a linear process. At the sideline of the G8 development ministerial meeting in Tokyo in April 2008, USAID administrator Henrietta Fore met with MOFCOM Vice Minister Yi Xiaozhun and proposed that the US and China launch a dialogue on development assistance issues, including aid management structures, lessons of aid delivery and the multilateral aid of the two countries. Yi rejected this proposal for a bilateral dialogue and suggested working-level meetings of aid officials as an alternative (Wikileaks, 2008a). Director Liu Junfeng from the MOFCOM DFA and USAID Office of Development Partners Director Karen Turner were then appointed as the point of contact. Yi also rebuffed Fore's proposal to include scholars, non-profit organisations, journalists and the private sector in the aid dialogue, stating that development economics is not yet a popular subject among Chinese academics (Wikileaks, 2008a).

This was the first vice ministerial-level meeting between China and the US on development cooperation. The US regarded Deputy Minister Yi's willingness to meet Fore as a positive step in our efforts to engage China and better understand its development goals and strategies' and 'a unique opportunity to lay the groundwork for our bilateral dialogue on foreign assistance' (Wikileaks, 2008e). In July 2009, MOFCOM Vice Minister Fu Ziying had a meeting with Anne-Marie Slaughter, director for policy planning at the US Department of State. The two sides discussed the potential dialogue on development cooperation and agreed to strengthen working-level communications (MOFCOM, 2009a).

China continued to show interest in expanding its development cooperation in Africa. The third China-US dialogue on Africa affairs was co-chaired by China Assistant Foreign Minister Zhai Jun and US Assistant Secretary of State for African Affairs Jendayi Frazer on 14 October 2008. The two sides exchanged views on their African policies and practices and agreed that they have vast common interests in promoting peace, security and development in Africa (MFA, 2008b). Zhai said that the approach of Chinese companies to their work in Africa is imperfect, that their international experience is shallow and that the Chinese government wants to learn from the US's rich experience in Africa and 
their aid programs to improve China's foreign aid approaches (Wikileaks, 2008d). He suggested that China and the US conduct pilot trilateral aid cooperation in Ethiopia, Ghana and Liberia (Wikileaks, 2008d).

Discussions between China and the US on development cooperation were not restricted to Africa. In November 2008, China and the US held their third dialogue on Latin American affairs in Beijing. The two sides agreed to maintain a dialogue and to explore further cooperation in this region (MFA, 2008a). The director-general from the MFA Department of Latin American Affairs, Yang Wanming, told US Assistant Secretary for Western Hemisphere Affairs Thomas Shannon that China is open to exploring and conducting trilateral aid cooperation with the US, as long as the views of the recipient Latin American countries are respected. He suggested that the two countries 'tackle easy issues before thorny ones' and that they promote development cooperation step by step (Wikileaks, 2008c). The USAID development counsellor at the US embassy in Beijing proposed the areas of potential cooperation, including health, environment, education and youth employment, and Yang asked for concrete project proposals for further considerations (Wikileaks, 2008c). With regard to Asia, China and the US held their fifth China-US consultation on Asian affairs in January 2014 and agreed to explore trilateral cooperation in areas such as the health sector in Myanmar and to continue their joint training of Afghan diplomats (US Department of State, 2014a).

\section{Obstacles for Trilateral Cooperation}

Although the US and China have increased engagement in development cooperation, only a small number of trilateral projects have materialised. David H. Shinn argued that this may be caused by a lack of enthusiasm from representatives of US embassies - particularly in African countriesand by the reluctance of China's embassies to become too closely linked to the US in Africa (Shinn, 2012b). For example, although China and the US agreed on a trilateral health assessment project in Liberia in 2010, the US proposal for a similar project in Ghana was rebuffed by the Chinese ambassador there (Lu Boynton \& Savoy, 2012, p. 8). The lack of interest from key Chinese and US personnel on the ground could also explain why, near the end of the Bush administration, the China-US discussions on pursing security sector reform in the Democratic Republic of Congo and irrigation cooperation in Ethiopia went nowhere (Shinn, 2011). Another obstacle is the insufficient number of aid officials and specialists 
that are posted to developing countries, when many Chinese economic and commercial counsellor's offices are understaffed. The aid officials face substantial difficulties in coping with the rapidly growing workload on bilateral aid, let alone in sparing time to manage trilateral cooperation (Interview with MOFCOM officials, Beijing, 4 August 2015).

The US agencies also have different views regarding development cooperation with China. The State Department has tended to focus on the positive aspects of the engagement, while the Treasury Department has emphasised the negative aspects, such as concerns about China's lending practices (Shinn, 2009, p. 7; Zhang, 2018). Moreover, reservations from African countries add to the complexity of trilateral aid cooperation. The proposed China-US-Angola trilateral agricultural project in 2007 failed to materialise, as the Angola side lacked interest in such cooperation (Shinn, 2009, p. 8). Some senior African officials doubted the benefits of trilateral cooperation for African countries (Wikileaks, 2010; Zhang, 2018), while some others also feared China-US cooperation might compromise China's non-interference policy that was strictly practised in China's bilateral aid projects in Africa (Shinn, 2012b). These obstacles could explain why the US's proposal to have a bilateral dialogue with MOFCOM on development cooperation in the autumn of 2008 was delayed until 2014 (Christensen \& Swan, 2008).

\section{China-US Global Development Dialogue}

Building on growing engagement and mutual understanding, the first China-US global development dialogue was held in Beijing on 29 April 2014. Liu Junfeng, deputy director-general of MOFCOM's DFA, and Alex Thier, assistant to the USAID administrator, co-chaired the dialogue. The two sides discussed potential development cooperation in areas including scholarly exchanges, training, research in science and technology (USAID, 2014; Zhang, 2018).

According to USAID, this global development dialogue, a platform for regular exchanges on development cooperation between the two countries, 'Is a landmark in US-China relations', and it 'provides opportunities for mutual learning through information exchanges' (USAID, 2014). Thier said that China 'exhibited a strong desire to engage with the US Government on global development issues related both to broad international policy as well as practical elements of implementation' (Thier, 2014, para. 5). MOFCOM also credited this inaugural dialogue 
as a priority achievement in its 2014 annual work review, which indicates its acceptance by senior MOFCOM officials (MOFCOM, 2015a; Zhang, 2018).

\section{Strategic and Economic Dialogue}

Trilateral aid cooperation between China and the US has received growing attention from the high-level political leaders of the two countries. It was discussed with an increasing level at the annual China-US strategic and economic dialogue (S\&ED), the highest level of regular mechanism between the two countries.

In 2009, then Secretary of State Hillary Clinton added development cooperation to the agenda of the China-US S\&ED and encouraged China to cooperate with the US to find 'tangible ways to work together on foreign aid' (Lu Boynton \& Savoy, 2012, p. 8; US Department of State, 2009). This discussion on development cooperation was upgraded, as USAID Chief Rajiv Shah and MOFCOM Deputy Minister Fu Ziying held a side meeting on development cooperation at the 2010 S\&ED dialogue (Lu Boynton \& Savoy, 2012, p. 8).

At the fourth meeting of the China-US S\&ED in May 2012, the two countries agreed to move further and conduct feasibility studies on trilateral aid programs and projects that would be 'agreed and selected by all parties, including the host country, in the fields of agriculture, health, and human resources' (US Department of State, 2012; Zhang, 2018). At the fifth meeting of the S\&ED in 2013, China and the US were committed to expanding their trilateral partnership from Afghanistan and Timor-Leste to other developing countries. They also identified potential areas for cooperation, such as regional integration, food and nutrition security, financial stability and inclusive and sustainable economic development in Africa, Latin America and Asia (US Department of State, 2013).

At the sixth dialogue meeting in 2014, China and the US agreed to continue their joint training of Afghan diplomats. At the bilateral Asia-Pacific consultation, the two countries pledged to conduct new trilateral projects in the region, such as health cooperation in Burma and Afghanistan, and to continue the trilateral agricultural project in TimorLeste (US Department of State, 2014b). At the seventh dialogue meeting in 2015, China and the US reaffirmed their commitment to conducting 
trilateral aid cooperation. They pledged to identify more trilateral aid projects in countries such as Afghanistan, Timor-Leste and other developing countries. They also agreed to strengthen their cooperation in the health sector in post-Ebola Africa (US Department of State, 2015).

At the sidelines of the seventh dialogue, the two countries hosted their first regular vice ministerial-level dialogue on development cooperation, which was co-chaired by Zhang Xiangchen, vice minister of MOFCOM, and Antony Blinken, deputy secretary of state of the US (Zhang, 2018). The two sides discussed issues, including post-Ebola recovery efforts, humanitarian assistance, disaster relief, finance for development and the post-2015 development agenda (USAID, 2015f); they agreed to establish a bilateral exchange and communication mechanism between USAID and MOFCOM (Lin, 2015), which materialised in September of that year. According to USAID, trilateral aid cooperation between the US and China demonstrated that in working together, the US and China can make a difference' (USAID, 2015f, p. 1).

\section{MOU on Development Cooperation}

Chinese President Xi Jinping's state visit to Washington in late September 2015 was an important diplomatic event in China. It also gave a final push to the China-US MOU on development cooperation and the establishment of an exchange and communication mechanism. As is common practice, China signed numerous agreements on cooperative projects with the US as achievements of President Xi's visit. Among them, the above MOU was signed between MOFCOM Minister Gao Hucheng and USAID Acting Administrator Alfonso Lenhardt (Lin, 2015).

According to the MOU, the two countries pledged to explore trilateral aid cooperation in areas such as poverty reduction, agriculture, education, health, humanitarian assistance and disaster prevention and response (USAID, 2015c). They will jointly establish disease prevention and control centres together with the African Union and its member states, and they will cooperate to improve the public health capacity in West African countries. China and the US will also strengthen their cooperation in the areas of humanitarian assistance, including by improving the disaster relief capacity in Third World countries and by continuing to support the UN international search and rescue advisory group (MOFCOM, 2015c). 
MOFCOM hails this MOU on development cooperation as 'a new highlight in China-US relations which has not only lifted their level of development cooperation but also added new substance to the bilateral relationship' (Lin, 2015, p. 2). More broadly, MOFCOM argued that the MOU demonstrated the appropriate ways that states should follow to deal with each other:

The aid from China and the US belongs to South-South cooperation and North-South Cooperation respectively ... This [the signing of the $\mathrm{MOU}$ ] has proven strongly that, as long as the two countries respect the core concerns of each other and do not impose their conception and systems on the other, it is definitely possible for them to seek common ground while putting? Aside the differences, reach consensus among them and the recipient countries, and conduct trilateral cooperation in areas of agreement. (MOFCOM, 2015c, paras 15-16)

\section{Evolving Trends in Aid to Timor-Leste}

This section will briefly introduce the evolving trends in aid to TimorLeste, including aid from the US and China. It will serve as the backdrop for the induction of the China-US-Timor-Leste trilateral aid project on food security.

Timor-Leste gained impendence on 20 May 2002, ending 24 years of Indonesian occupation. As a young nation, Timor-Leste has received a large amount of aid from both traditional and emerging donors, totalling to approximately $\$ 8$ billion (da Costa, 2015 , p. 6). As Timor-Leste's MoF noted, 10 bilateral and eight multilateral donors committed aid to TimorLeste in 2015. Among them, Australia, the European Union, Portugal, Japan, New Zealand, the ADB, Germany and the World Bank are the top donors, who contributed approximately 84.5 per cent of total (grant) aid to the country (Timor-Leste Ministry of Finance, 2014a, p. 7). China, Brazil and Cuba are the three emerging donors in Timor-Leste, focusing on infrastructure, education and vocational training, as well as public health in rural areas (da Costa, 2015). 
According to Dr Helder da Costa, secretary-general of the G7+ and senior advisor to the Timor-Leste government on aid effectiveness, the trends in aid to Timor-Leste have changed dramatically in the past decade. The total aid volume to Timor-Leste was about $\$ 70$ million in 2002. It surged to $\$ 300$ million in 2003 and then fluctuated between $\$ 180$ and $\$ 250$ million in the past five years due to the lack of donors' predictability (Interview, Dili, 3 February 2015). It remained around $\$ 250$ million per annum from 2011 to 2013 , and a total of $\$ 165.5$ million in aid was committed for 2015 (Timor-Leste MoF 2014a, p. 6). In 2018, development partners committed $\$ 181.73$ million in grants and $\$ 61.6$ million in concessional loans to Timor-Leste (Timor-Leste MoF, 2018, p. 9).

Timor-Leste's dependence on foreign aid has been decreasing rapidly due to the influx of oil revenue from its petroleum fund. ${ }^{3}$ Timor-Leste has remained highly dependent on this fund, which provides 95 per cent of the national income (Leach, 2016, p. 469). The ratio of foreign aid as a percentage of the state budget has dropped from 86 per cent in 2002 to 16 per cent in 2012, and further down to 12 per cent in 2018 (da Costa, 2015, p. 7; Timor-Leste MoF, 2018, p. 9)-a sharp contrast to the case of Cambodia, as discussed in the previous chapter.

In terms of US aid, the US conducted 54 aid projects through USAID and its embassy in Dili from 2005 to 2015. The actual disbursements of these projects amounted to $\$ 125.6$ million, as illustrated in Table 14.

Table 14. US aid (grant) projects in Timor-Leste, 2005-2015

\begin{tabular}{|l|r|r|}
\hline Project number & Actual commitments USD & Actual disbursements USD \\
\hline US (54) & $143,581,333$ & $125,605,118$ \\
\hline USAID (42) & $143,489,998$ & $125,499,233$ \\
\hline Embassy of the US (12) & 91,335 & 105,885 \\
\hline
\end{tabular}

Source. Compiled by the author from the Timor-Leste MoF aid transparency portal.

3 Timor-Leste Petroleum Fund was set up in 2005. All oil revenues are required to go be included in the fund. They are then used to invest in overseas financial assets and support the state budget. 


\section{Chinese Aid in Timor-Leste}

China's assistance to Timor-Leste dates back to the resistance period, when Timor-Leste was occupied by Indonesia in the 1970s. China was one of the first countries to recognise the Democratic Republic of Timor-Leste in $1975 .{ }^{4}$ China provided diplomatic and financial support to TimorLeste, even including weaponry, though Indonesian forces intercepted this (Interview with a senior Timor-Leste official, Dili, 6 February 2015). China's presence in Timor-Leste is felt as an emerging non-traditional donor (da Costa, 2015). Figure 22 and Table 15 depict China's foreign aid (grants) to Timor-Leste from 2006 to $2015 .{ }^{5}$ During this period, the actual disbursement of China's aid to Timor-Leste reached $\$ 60.4$ million, $\$ 8.9$ million more than it committed. This is further evidence of China's growing foreign aid outlay. China announced in November 2013 that it would increase its aid to Timor-Leste to approximately $\$ 15.4$ million (RMB 100 million) a year (Horta, 2014).

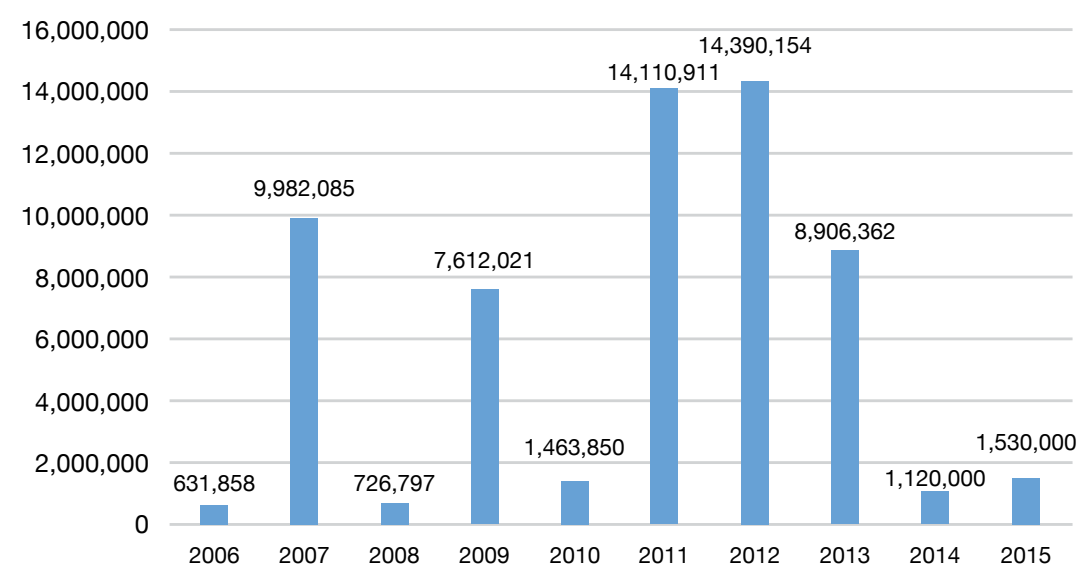

Figure 22. Chinese aid to Timor-Leste, USD

Source. Compiled by the author from the Timor-Leste MoF aid transparency portal.

4 On 28 November 1975, the Revolutionary Front for an Independent East Timor (Fretilin) declared the founding of the Democratic Republic of Timor-Leste, 10 days before the Indonesian occupation.

5 Figure 22 and Table 15 are based on data from the Aid Transparency Portal of Timor-Leste Ministry of Finance. The calculations based on actual disbursement lead to the fluctuation in the chart because some Chinese aid projects, especially the large infrastructure projects, will take a few years to complete. The years of project completion usually have high figures. The aid data before 2006 is unavailable. 
Table 15. Chinese aid (grant) projects in Timor-Leste, 2006-2015

\begin{tabular}{|l|r|r|}
\hline & $\begin{array}{r}\text { Actual } \\
\text { commitments }\end{array}$ & $\begin{array}{c}\text { Actual } \\
\text { disbursements }\end{array}$ \\
\hline 17 projects, USD & $\mathbf{5 1 , 5 5 5 , 2 5 6}$ & $\mathbf{6 0 , 4 7 4 , 0 3 9}$ \\
\hline X-ray scanner for customs & $7,906,763$ & $8,033,419$ \\
\hline 8,500 tons of rice & $7,465,636$ & $7,465,636$ \\
\hline $\begin{array}{l}\text { Construction of Timor Leste Defence Force } \\
\text { (F-FDTL) HQ }\end{array}$ & $6,367,748$ & $6,907,942$ \\
\hline MFA Office Building (2) & $6,033,430$ & $9,316,613$ \\
\hline Chinese medical team & $5,731,513$ & $9,769,472$ \\
\hline $\begin{array}{l}\text { President's office (geological survey, construction } \\
\text { and maintenance) }\end{array}$ & $4,063,306$ & $6,880,096$ \\
\hline Study centre for diplomats & $3,303,861$ & $1,682,692$ \\
\hline $\begin{array}{l}\text { Construction of flood-control project of 100 } \\
\text { quarters for the F-FDTL (2) }\end{array}$ & $2,661,032$ & $2,697,257$ \\
\hline Construction of 100 quarters for the F-FDTL & $2,488,545$ & $2,654,176$ \\
\hline $\begin{array}{l}\text { Construction of China-aided medical team } \\
\text { dormitory project }\end{array}$ & $2,290,208$ & $2,090,000$ \\
\hline Construction of a primary school & 731,925 & 731,925 \\
\hline President's office building technical cooperation & 600,179 & 328,526 \\
\hline 50,000 sets of blankets & 548,632 & 512,348 \\
\hline Furniture for the office building of MFA & 439,181 & 470,995 \\
\hline Furniture for the F-FDTL office building & 395,908 & 401,606 \\
\hline Six ambulances for the Ministry of Health & 314,980 & 321,337 \\
\hline $\begin{array}{l}\text { Three-party cooperation on agriculture between } \\
\text { China, US and Timor-Leste }\end{array}$ & 212,408 & 210,000 \\
\hline
\end{tabular}

Source. Compiled by the author from the Timor-Leste MoF aid transparency portal.

In the process of advancing south-south cooperation in Timor-Leste, China has been strategic in providing large infrastructure aid projects that are quite visible within the country. The following China-aided buildings stand as landmark architectures in Dili: the MFA building (China's first turnkey project in Timor-Leste); the Presidential Palace; the Ministry of Defence building; and the Headquarters of the Defence Force. Though unpopular with many ordinary people who notice no direct benefits from the projects, these infrastructure projects are needed by the recipient governments and thus draw China and others closer together. Moreover, it seems relatively easy to obtain aid from China than from traditional donors, who require lengthy and stringent procedures. As Vicky Tchong, the Timorese ambassador to China, said: 'We can get almost anything we want from China; all we need to do is to ask' (Horta, 2014). 
Technical assistance projects are also conducted by China. A good example is the hybrid rice project that was contracted to the Long Ping High Tech Agriculture Corporation Limited over the period 2008-2015. China provided rice seeds, fertiliser and agrochemicals as well as technical instructions. The experimentation was conducted in districts including Manatuto, Baucau, Lautem, Bobonaro and Viqueque (China Embassy in Timor-Leste, 2011). Timor-Leste has also actively participated in China's short-term training and scholarship programs. More than 600 Timor-Leste public servants attended training in China in 2013 alone, and 1,236 Timor-Leste Students had studied in China by February 2014 (Horta, 2014). China also channels aid to Timor-Leste through the Forum for Economic and Trade Cooperation between China and Portuguesespeaking countries.

In contrast to Cambodia where the majority of Chinese aid projects take the form of concessional loans, Timor-Leste has just started to approach China for concessional loans. In 2009, Timor-Leste Foreign Minister Zacarias da Costa revealed that his country was negotiating a loan from China to finance infrastructure projects (Macao Hub, 2009). In 2010, Timor-Leste President Ramos Horta requested a loan of $\$ 3$ billion from Chinese Premier Wen Jiabao (Horta, 2014). In December 2015, the China Exim Bank agreed to provide a concessional loan of $\$ 50$ million to Timor-Leste for the construction of the drainage system in Dili over the next three to five years (Forum Macao, 2015; Timor-Leste MoF, 2014b). This was China's first concessional loan to Timor-Leste.

\section{China-US-Timor-Leste Trilateral Project on Food Security}

This trilateral project was initiated by the US and China in close discussion with Timor-Leste Ministry of Agriculture and Fisheries (MAF) (Interview with Lourenco Fontes, Dili, 19 January 2015). ${ }^{6}$ In July 2011, US Secretary of State Hillary Clinton and China's Foreign Minister Yang Jiechi announced the two countries' intention to conduct a trilateral agricultural aid project in Timor-Leste (US Department of State, 2011). In September 2012, Hillary Clinton visited Timor-Leste, which was the first trip by a US secretary of state to visit the country. According to the

6 Lourenco Fontes, director-general of Timor-Leste MAF. 
accompanying US officials, Secretary Clinton had the desire to increase aid coordination with China in Timor-Leste (Lakshmanan, 2012). As discussed earlier, Hillary Clinton and Dai Bingguo, China's state councillor in charge of foreign affairs, agreed at their bilateral S\&ED in May 2012 that the two countries would collaborate on development cooperation in the areas of health and agriculture (US Department of State, 2012).

In February 2013, a joint scoping mission of nine Chinese and US experts visited Timor-Leste to realise the above commitment. They assessed local conditions and discussed potential areas for trilateral aid cooperation (USAID, 2013, p. 2). During the visit, the three countries agreed to support the Timor-Leste MAF strategic plan 2014-2020 to build human capacity through training and technical assistance (Email interview with USAID official involved in the trilateral project, Canberra, 14 January 2015). To be more specific, they reached a consensus to focus their first trilateral project on increasing Timorese farmers' knowledge and capacity building to in turn increase the production of selected crops (Interview with Lourenco Fontes, Dili, 19 January 2015).

On 30 October 2013, the formal signing ceremony of the project occurred in Dili. China's Economic and Commercial Counsellor Ding Tian from the embassy in Dili, Acting USAID Director in Dili Sandra Minkel and Director-General Lourenco Borges Fontes from Timor-Leste MAF signed the agreement on behalf of their governments (Interview with Lourenco Fontes, Dili, 19 January 2015).

The core of this project is agricultural technical assistance. The main stakeholders include MOFCOM, USAID and Timor-Leste MAF. China and the US provided short-term training and technical assistance to Timor-Leste participants, targeting selected crops that included staple crops of maize and beans and cash crops of onions and garlic. In terms of labour division, China concentrated on the cultivation of maize, while the US focused on beans, onions and garlic. Timor-Leste MAF provided training facilities and the field side for demonstration plots, and organised participants to attend the training (Interview with Lourenco Fontes, Dili, 19 January 2015). The beneficiaries of the project included smallholder farmers, extension specialists from Timor-Leste MAF, agriculture students from the National University of East Timor and the NGO/donor program staff and lead farmers (Interview with Lourenco Fontes, Dili, 19 January 2015). 
The official project was conducted between October 2013 and January 2015. From the US side, this trilateral project was a part of USAID's DAC project. With a contract value of $\$ 8.28$ million, the whole DAC project (July 2010 - February 2015) aimed to assist Timorese farmers to move towards more diversified and income-generating farming, as well as to link with the market through technical training. Development Alternative Inc., a US-based private development company, was the US contractor for DAC-including this China-US-Timor-Leste trilateral project (USAID, 2015b). The Chinese contractor for the trilateral project was Long Ping High Tech Agriculture Corporation Ltd, which had been responsible for the hybrid rice demonstration project in Timor-Leste since 2008.

The main demonstration plot was located in Kotolau, Aileu district, 6 kilometres southeast of the capital of Dili. Chinese and US agricultural experts jointly hosted in-class training programs at this plot, with each side focusing on their own selected crops. The experts lectured in Chinese and English, respectively, with translation into Tetum, one of two official languages of Timor-Leste. Numerous topics were covered in the lectures, ranging from land preparation to planting and harvesting (Interview with Tobias dos Santos, Dili, 6 February 2015). ${ }^{7}$ However, China and the US conducted their in-the-field technical assistance parts separately. USAID conducted some of their own activities in other demonstration plots, such as in Bobonaro district and Ainaro district (Interview with Lourenco Fontes, Dili, 19 January 2015).

This pilot technical assistance project had a small aid volume. China and the US were responsible for paying for their own agricultural experts. China's actual disbursement was approximately $\$ 210,000$ (Timor-Leste MoF, 2015). The US disbursement is unknown, as the trilateral project is a part of the abovementioned DAC project of $\$ 8.28$ million. More than 120 Timorese participated in China’s five training sessions, each with a duration of two months (Interview, Dili, 3 February 2015).

A joint mission comprising officials and experts from China, the US and Timor-Leste conducted a final assessment of the trilateral project in April 2015 (USAID 2015f). Overall, the three partner countries expressed their satisfaction with the project's results. China and Timor-Leste wanted to

7 Tobias dos Santos, coordinator of extension workers from Timor-Leste MAF and four students from the National University of East Timor, who participated in the project training. 
conduct a second phase (Interviews with Chinese aid experts and TimorLeste MAF officials, Dili, 2, 3 and 6 February 2015). A senior official from Timor-Leste MFA said:

This project is an experimental thing, looks good and the result is amazing ...We hope to continue and expand trilateral cooperation. We are thinking of expanding trilateral cooperation in the future, maybe in agriculture, or other areas. (Interview, Dili, 29 January 2015)

Coordination was maintained during the project, though its extent was debated (Interviews with Lourenco Fontes, Chinese and US aid officials, Dili, 19 January and 4, 10 and 23 February 2015). Some Timor-Leste officials and student participants suggested that China's agricultural training should provide more detailed information rather than general theories and it should involve more participants in the whole cultivation process rather than just in the harvesting process (Interview with Tobias dos Santos, Dili, 6 February 2015). Relative to China and Timor-Leste, the US was more cautious about its assessment of the project. While acknowledging the achievements, it identified areas to be improved, including the selection of a demonstration site that was appropriate to the selected crops, clearly defining the responsibilities and strengthening the coordination (Interview with USAID officials and experts, Canberra, 14 January; Dili, 4 and 10 February 2015).

\section{China's Motivations}

The Chinese government has used this trilateral aid project as a diplomatic tool to build its cooperative image for managing bilateral relations with the US. The Chinese government and officials have emphasised the importance of promoting cooperation in China-US relations for the benefits of both countries. For example, China's then Deputy Foreign Minister Zhang Zhijun noted that 'if China and the US could not even cooperate in Asia-Pacific, how can they talk about cooperation globally' (Wang, 2011, para. 4). Chinese President Xi Jinping made this point clearer at the opening ceremony of the sixth round of the China-US S\&ED in 2014: 'Both history and reality have shown that cooperation between China and the US will benefit both whereas confrontation will hurt both' (MFA, 2014a). In practice, the Chinese government has been working hard to persuade the US to build a new type of relation 
between two powers. Exploring cooperation with Washington DC in the development sector has been part of China's efforts in recent years, as was previously illustrated in their engagement since the late 1990s.

In this context, the Timor-Leste trilateral project has received substantial attention from China's leadership. It is the only project that is highlighted in the outcome list of President Xi Jinping's state visit to the US in September 2015 (MFA, 2015d). Together with the joint training program of Afghan diplomats, it is mentioned by Yang Jiechi, China's state councillor, as an example of cooperation in China-US bilateral relations (Yang, 2015).

In January 2014, Chinese Ambassador to Timor-Leste Tian Guangfeng visited the trilateral project and met with the Chinese agricultural experts from Long Ping High Tech, China's contractor for the project. His remarks provided clues regarding how the Chinese government has approached this project:

The China-US-Timor-Leste trilateral agricultural project is the first agricultural project of cooperation between China and the US since the founding of the People's Republic of China. We need to fully commit ourselves to the project. This project carries a heavy political significance. It should show the image of China's foreign aid projects to the outside world ... Ambassador Tian encouraged the Chinese agricultural mission to increase coordination with the US and Timor-Leste side and make this trilateral project 'a model of China's multilateral cooperation'. (Long Ping High Tech, 2014, para. 3; MOFCOM, 2014c, para. 1)

Aid officials from China, the US and Timor-Leste confirm that this project is the result of the strong commitment from senior politicians in the US and China. A senior official from the CAITEC (MOFCOM's think tank) revealed that the project was raised by China's MFA rather than MOFCOM. To this official, the project was designed to serve the China-US bilateral relations, as the two countries have been including development cooperation as a topic in their S\&ED and they want to have something substantial (Interview, Beijing, 4 August 2015). This point received support from USAID official (Interview, Beijing, 5 August 2015), Gil Rangel da Cruz, executive secretary of food security and cooperation from Timor-Leste MAF, and his colleague, Octavio da Costa Monteiro de Almeida, director-general of planning (Interview, Dili, 2 and 3 February 2015). 
China is also keen to promote its image as a responsible power among small states including Timor-Leste by delivering aid, including trilateral aid cooperation. On 20 May 2002, China became the first country to establish diplomatic relations with Timor-Leste, and Chinese aid flowed in. As China's Ambassador Tian Guangfeng said in 2012, the two countries have built the relationship 'into a perfect example of equality between large and small countries' (Tian, 2012, para. 2). Timor-Leste President Taur Matan Ruak said in September 2012 that 'Timor-Leste and China are allies for the purpose of alleviating poverty and promoting development' (Ruak, 2012, para. 11). To China, trilateral aid cooperation could serve as a new modality for combining China's strength in southsouth cooperation, with the useful aid practices of traditional donors.

Agriculture is chosen due to its significance as a pillar industry in TimorLeste. More than 70 per cent of families in the country rely on some sort of farming activity for their survival (Timor-Leste Government, 2011, p. 108). However, agricultural development in Timor-Leste faces tremendous challenges, including the shortage of knowledge. For example, though the agricultural GDP of Timor-Leste grew by just 2.9 per cent between 2000 and 2007, the production of major food crops-especially rice and maize - and cash crops was erratic and exhibited a very low productivity (Timor-Leste Ministry of Agriculture and Fisheries, 2012, p. 7). Agriculture has been listed as a focus for development by TimorLeste in its strategic development plan 2011-2030 and the strategic plan 2014-2020 (Timor-Leste Government, 2011; Timor-Leste Ministry of Agriculture and Fisheries, 2012). The improvement and value addition of agricultural research and technology development are listed as two strategic objectives (Timor-Leste Ministry of Agriculture and Fisheries, 2012, p. xiii). Development targets have been set. For example, maize productivity is expected to increase from 1.25 metric tons/hectare (Mt/ha) to $1.54 \mathrm{Mt} / \mathrm{ha}$ by 2015 and to $2.5 \mathrm{Mt} / \mathrm{ha}$ in the period from 2016 to 2020 (Timor-Leste Ministry of Agriculture and Fisheries, 2012, p. 15). In April 2014, China signed an agreement with visiting TimorLeste Prime Minister Kay Rala Xanana Gusmão. The two sides agreed to establish a comprehensive partnership and pledged to 'continue strengthening cooperation in food production and agricultural capacity building' (MOFCOM, 2014c). Therefore, Octavio da Costa Monteiro de Almeida, director-general of planning from Timor-Leste MAF, said that we decided to have cooperation in the area of food security and nutrition [in this trilateral project] because it is one of the important issues for Timor-Leste' (Interview, Dili, 3 February 2015). 
Timor-Leste is a small nation and the low sensitivity of the agricultural sector is conducive to the initiation of this experimental project. This is also supported by the argument from Dr Helder da Costa: this project focused on agriculture in Timor-Leste because it had nothing to do with the strategic interests of China and the US, and 'the degree of friction is minus' (Interview, Dili, 10 February 2015).

Though the learning imperative was a less prominent factor compared to image building, China was also interested in learning from US practices in foreign aid and agriculture. As a Chinese senior official for this project noted:

China agrees to conduct this trilateral project because China also wants to learn from the US agricultural technologies. For instance, China's previous technological breakthroughs in the sector of maize are closely linked to China's learning from the US. The US has mature experiences in areas including agricultural technologies and market promotion of agricultural products. China attaches importance to agricultural research, but there are gaps in areas such as market promotion. So, through this kind of trilateral project including even the US training materials, China wants to learn from US practices in these areas. (Interview, Dili, 3 February 2015)

China's desire to learn from US aid practice does not contradict the fact that experts from the two donor countries worked separately in some aspects of this trilateral project, such as on different selected crops and on harvesting separately. As trilateral cooperation is a new aspect in the China-US relations, working jointly on everything in a trilateral project is too ambitious at this stage. In addition to this learning desire, China is showing interest in testing trilateral cooperation as a new modality for promoting aid effectiveness. As early as 2010, China's Ambassador to Timor-Leste Fu Yuancong said:

Under the framework of South-South cooperation, China will work with all parties concerned to conduct complementary and fruitful trilateral and regional cooperation on the basis of respecting the needs of recipient countries and jointly promote the process of global poverty alleviation. (Fu, 2010) 


\section{US's Motivations}

The US has similar motivations. This trilateral project is mainly designed to serve its diplomatic relations with China - a rapidly growing power. As the detailed discussion in Section Two has demonstrated, the US government has dedicated growing efforts to engaging with China, a rapidly growing power, and to shaping it into a responsible stakeholder. It has regarded development cooperation as an important and less sensitive sector for enriching broader US-China bilateral relations. The US has expanded its conversations with China regarding aid cooperation and has even included the topic in the bilateral S\&ED in recent years.

At the signing ceremony of the China-US-Timor-Leste trilateral project in 2013, Scott Ticknor, chargé d'affaires from the US Embassy in Dili, lauded the project: 'This trilateral endeavor is a testament to our [US-China] mutual commitment to peace and prosperity in TimorLeste, and reflects new types of partnership in the Southeast Asia region' (US Embassy in Timor-Leste, 2013, para. 2). Katherine Duffy Dueholm, deputy chief of mission of the US Embassy in Dili, concurred with this view: ${ }^{8}$

The goal of this trilateral project is to build confidence between China and [the] USA, and to bring the two countries together. It is a good thing to do a trilateral project. Cooperation in development and foreign aid is part of the broad China-US bilateral relations and bilateral cooperation. (Interview, Dili, 10 February 2015)

Promoting the understanding of China's foreign aid and integrating it into the international aid system is another motivation of the US. By engaging China in development cooperation, the US wants to 'encourage China to adopt internationally agreed standards on good donorship' (United States Agency for International Development, 2010). Richard L. Greene, deputy director of foreign assistance from the US Department of State, said at the 2008 high-level segment development cooperation forum of the UN Economic and Social Council that the US should work with other donors to sustain development progress (Greene, 2008 , p. 2). A Chinese aid expert argued that this trilateral project also

8 Similar views have been expressed by Chinese aid officials and scholars during the author's interviews (Beijing, August-September 2015). 
relates to the US's desire to learn from China's small-scale agricultural practices due to the similarities of small-scale agriculture in Timor-Leste (Interview, Dili, 3 February 2015).

In addition, the US has hoped to promote agricultural development in Timor-Leste through trilateral partnership. USAID has identified the inclusive development in agriculture in Timor-Leste as a central task in its five-year development strategy (2013-2018) (USAID, 2015b). It has pledged to 'place increased focus on improving agriculture productivity in terms of responding to the food crisis' (Greene, 2008, p. 5). While the Chinese side focused on the production of selected crops, the US focused on both production and marketing in their part of the project (Interview, Dili, 19 January 2015).

\section{Timor-Leste's Motivations}

Promoting cooperation among other powers on its soil is one major motivation of the Timorese government, and it serves its interest. TimorLeste finds life easier and more comfortable with China and the US cooperating rather than competing in the country. Timor-Leste Foreign Minister Jose Luis Guterres noted in 2013 that he was interested in US Secretary of State Hillary Clinton's remark that 'the Pacific is big enough for all of us', as this means that there are opportunities for the US to cooperate with China in the Pacific (Everingham, 2013). The TimorLeste government has been keen to hail this trilateral agricultural project as a diplomatic triumph. During his attendance at the World Food Day celebrations on 16 October 2013, Timor-Leste President Taur Matan Ruak was proud to announce that 'these two giant countries [China and the US] never work together. Only Timor-Leste can unite these countries under the trilateral cooperation in agriculture development' (Interview with Lourenco Fontes, Dili, 19 January 2015).

Another motivation of the Timorese government is to strengthen its ownership of foreign aid through various means, including trilateral partnership. As the former head for aid effectiveness at Timor-Leste MoF, Dr Helder da Costa highlighted the issue of donor fragmentation in Timor-Leste and emphasised that 'donors need to be on listening mode' and 'the country (Timor-Leste) must own their development agenda' (da Costa, 2015, pp. 5, 11). Much progress has been achieved. In 2012, the development partnership management unit was established within Timor-Leste's MoF to ensure the effective use of foreign aid and 
to promote aid coordination and harmonisation (Timor-Leste Ministry of Finance, 2014a, p. 6). An aid transparency portal has been established under the $\mathrm{MoF}$ as the online database to record all aid flows to TimorLeste (Timor-Leste Ministry of Finance, 2014a, p. 6). Timor-Leste was also among the founding members of the G7+, an intergovernmental organisation that addresses post-conflict development challenges that fragile states face, including through the better use of foreign assistance and through promoting recipient-led strategies for development and south-south cooperation. This trilateral project is one such attempt to promote aid coordination. It is regarded as 'an attempt to reach out using each other's comparative advantages and helping' (Interview, Dili, 3 February 2015).

\section{Conclusion}

This chapter has examined the China-US engagement on development cooperation in recent years. In particular, it has traced the process of this engagement against the backdrop of China-US relations since 1990s and has explored the China-US-Timor-Leste trilateral aid project on food security in detail. One caveat is that, in light of the difficulty in accessing data in China and the US, some data from Wikileaks has been used, especially in the section on China-US high-level engagement in development cooperation. To maximise the data's reliability, I have made every effort to triangulate the data with the available and released official data-such as those by China MFA, Chinese official media and the US Department of State.

This chapter concludes that the learning imperative has played a minor role in China's conduct of trilateral aid cooperation with the US due to the short history of US aid to China. On the contrary, image building has been China's main driving force to pilot a trilateral partnership with the US. The purpose is to project China's image as a responsible stakeholder in development assistance to serve the broader China-US relationship. This point is similar to what I found in Chapters 4 and 5 regarding China's trilateral aid cooperation with the UNDP and Australia in Cambodia and PNG.

China and the US have agreed to build their trilateral development cooperation in Africa as 'a highlight and a new area of cooperation in the new model of China-US relations' (MFA, 2014b, para. 2). At the 
eighth China-US S\&ED, the two donors pledged to expand their trilateral aid cooperation by continuing the joint training program for young Afghan diplomats, providing similar training for Afghan health and agricultural workers, exploring new areas of cooperation, exploring trilateral cooperation in Timor-Leste on aquaculture, exploring trilateral aid cooperation on food security in Africa and jointly supporting the goals and objectives of the comprehensive Africa agriculture development program (US Department of State, 2016).

However, trilateral cooperation between US and China is still in the early stage of experimentation, and progress should not be taken for granted. The pilot projects are small in scale and are technically based. Potential is there, but obstacles remain-including bureaucratic decentralisation, differences in development assistance goals, divergent methods of aid delivery, capacity gaps and other political considerations (Lu Boynton \& Savoy, 2012, p. 9). Trust building takes time. For example, as a development expert mentioned, many MOFCOM officials were not receptive when USAID sent Jennifer Adams as the first development counsellor to China in September 2008. The longstanding mistrust between the two countries is deeply rooted and likely to remain (Lawrence, 2013 , p. 2). More information and transparency from both sides are needed. The most challenging areas relate to democracy, good governance and human rights. Further dialogue on these difficult issues must also be promoted. The reactions from recipient countries are also mixed and demand further attention.

What deserves our special attention is the growing uncertainty in ChinaUS relations since 2017 that has become a major obstacle for their trilateral aid cooperation. The Trump administration explicitly views China as a strategic rival and emphasises competition with the country. The $\mathrm{Xi}$ Jinping administration has seemingly behaved uncompromisingly in response. Affected by the heightened tensions in the bilateral relations, the two countries have suspended their trilateral aid cooperation, including cancelling the second phase of the planned trilateral aid project in TimorLeste. In the future, if China-US bilateral relations improve, trilateral aid cooperation between the two countries is expected to grow steadily. If they do not improve, then the prospect of development cooperation would be bleak. 
Tips from Professor Li Anshan, a senior expert on China-Africa relations at Peking University, are thought provoking. He cautions that China and the US should address a few questions before they can conduct genuine trilateral aid cooperation: 'Should we provide our help to African countries with aid conditions?', 'Can we decide the issue for Africans?' and 'Can we decide what Africa needs?' (Freeman III \& Lu Boynton, 2011, pp. 44-45). To Professor Anshan, China and the US should reach an agreement on understanding 'condition' in Chinese terms and 'aid' in US terms; on choosing a proper project for cooperation; on choosing an African country as a partner and seeking their approval on the project; and on devising a clear division of responsibilities and ownership for the pilot project (Freeman III \& Lu Boynton, 2011, pp. 45-46).

The following remarks provide some answers to the above questions. Following the advice here might be a way to ease the process of securing trilateral aid cooperation with China in the future. During a meeting with US Assistant Secretary for African Affairs Jendayi Frazer in October 2008, China Assistant Foreign Minister Zhai Jun said that further development cooperation with the US was possible, but that three principles had to be observed:

First, respect the views of Africans and do not impose outside views on African countries. Second, seek to gradually increase cooperation, starting with countries with which the United States and China both enjoy good relations and focusing on concrete, small-scale projects in agriculture and health. Third, use existing mechanisms and framework rather than setting up new mechanisms for cooperation. (Wikileaks, 2008d) 
This text is taken from A Cautious New Approach: China's Growing Trilateral Aid Cooperation, by Denghua Zhang, published 2020 by ANU Press, The Australian National University, Canberra, Australia.

doi.org/10.22459/CNA.2020.06 